\title{
Moisture effects on carbon and nitrogen emission from burning of wildland biomass
}

\author{
L.-W. A. Chen ${ }^{1}$, P. Verburg ${ }^{2}$, A. Shackelford ${ }^{2}$, D. Zhu ${ }^{1}$, R. Susfalk ${ }^{3}$, J. C. Chow ${ }^{1}$, and J. G. Watson ${ }^{1}$ \\ ${ }^{1}$ Division of Atmospheric Sciences, Desert Research Institute, Reno, NV 89512, USA \\ ${ }^{2}$ Division of Earth and Ecosystem Sciences, Desert Research Institute, Reno, NV 89512, USA \\ ${ }^{3}$ Division of Hydrological Sciences, Desert Research Institute, Reno, NV 89512, USA
}

Received: 26 February 2010 - Published in Atmos. Chem. Phys. Discuss.: 26 March 2010

Revised: 1 July 2010 - Accepted: 1 July 2010 - Published: 20 July 2010

\begin{abstract}
Carbon $(\mathrm{C})$ and nitrogen $(\mathrm{N})$ released from biomass burning have multiple effects on the Earth's biogeochemical cycle, climate change, and ecosystem. These effects depend on the relative abundances of $\mathrm{C}$ and $\mathrm{N}$ species emitted, which vary with fuel type and combustion conditions. This study systematically investigates the emission characteristics of biomass burning under different fuel moisture contents, through controlled burning experiments with biomass and soil samples collected from a typical alpine forest in North America. Fuel moisture in general lowers combustion efficiency, shortens flaming phase, and introduces prolonged smoldering before ignition. It increases emission factors of incompletely oxidized $\mathrm{C}$ and $\mathrm{N}$ species, such as carbon monoxide $(\mathrm{CO})$ and ammonia $\left(\mathrm{NH}_{3}\right)$. Substantial particulate carbon and nitrogen (up to 4 times $\mathrm{C}$ in $\mathrm{CO}$ and $75 \%$ of $\mathrm{N}$ in $\mathrm{NH}_{3}$ ) were also generated from high-moisture fuels, maily associated with the pre-flame smoldering. This smoldering process emits particles that are larger and contain lower elemental carbon fractions than soot agglomerates commonly observed in flaming smoke. Hydrogen $(\mathrm{H}) / \mathrm{C}$ ratio and optical properties of particulate matter from the highmoisture fuels show their resemblance to plant cellulous and brown carbon, respectively. These findings have implications for modeling biomass burning emissions and impacts.
\end{abstract}

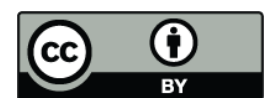

Correspondence to: L.-W. A. Chen (antony.chen@dri.edu)

\section{Introduction}

On a global scale, biomass burning is an important process mobilizing carbon $(\mathrm{C})$ and nitrogen $(\mathrm{N})$ from the biosphere to the atmosphere, with $2-5 \times 10^{15} \mathrm{~g}$ of $\mathrm{C}$ and $15-46 \times 10^{12} \mathrm{~g}$ of $\mathrm{N}$ burned and released each year (Crutzen and Andreae, 1990). C emissions in the form of greenhouse gases, including carbon dioxide $\left(\mathrm{CO}_{2}\right)$ and methane $\left(\mathrm{CH}_{4}\right)$, are known to contribute to climate change (IPCC, 2007). $\mathrm{N}$ is an essential nutrient for all living organisms, and its emissions in the form of nitrous oxide $\left(\mathrm{N}_{2} \mathrm{O}\right)$, nitrogen oxides $\left(\mathrm{NO}_{\mathrm{x}}\right)$, ammonia $\left(\mathrm{NH}_{3}\right)$, particulate nitrogen, etc. can be utilized by the living organisms and therefore impact the ecosystem (Vitousek et al., 1997). In addition, many of the $\mathrm{C}$ - and/or N-containing volatile and particulate components from biomass burning play vital roles in radiative forcing, atmospheric chemistry, and air pollution (Keil and Haywood, 2003; Kondo et al., 2004; Crounse et al., 2009). The fate (i.e., atmospheric lifetime) and effects of $\mathrm{C}$ and $\mathrm{N}$ from biomass burning depend on how they are distributed between gaseous and particulate phases and among various species. The dry deposition velocity of $\mathrm{NH}_{3}$, for instance, is at least 10 times that of $\mathrm{NO}_{\mathrm{x}}$ (Neirynck et al., 2007). $\mathrm{N}$ in $\mathrm{NH}_{3}$ more likely remains close to where biomass burning occurs rather than being removed from the source region due to long-range transport.

Emission rates and compositions are sensitive to fuel type and combustion conditions (e.g., fuel load, moisture content, and wind). Flaming combustion involves a more complete oxidation, converting $\mathrm{C}$ and $\mathrm{N}$ to $\mathrm{CO}_{2}$ and $\mathrm{NO}_{\mathrm{x}}$, respectively, than smoldering combustion (Koppmann et al., 2005; Chen et al., 2007). Particles are generated from both flaming

Published by Copernicus Publications on behalf of the European Geosciences Union. 
and smoldering phases, but they differ in size, morphology, and optical properties (Reid et al., 2005a, b; Chen et al., 2006; Chakrabarty et al., 2006; McMeeking et al., 2009). Light-absorbing black carbon with a structure similar to soot agglomerates dominates in high temperature flames, while smoldering particles are whiter and more spherical in shape. Particle hygroscopicity increases with the inorganic fraction of particulate mass which depends more on fuel type than on combustion conditions (Carrico et al., 2010).

Laboratory experiments are useful for controlling and investigating individual parameters effecting the biomass burning emission. The Fire LAb at Missoula Experiments (FLAME I and II) conducted in 2006 and 2007 investigated a wide range of biomass types and loads in a laboratory combustion system (McMeeking et al., 2009). Fuels used during the FLAME study were either fresh or dried sufficiently to readily ignite. A systematic investigation of the fuel moisture effect on biomass burning was not part of FLAME I and II and is rarely reported in the literature. However, moisture contents of wildland biomes could vary corresponding to climate and weather conditions, substantially influencing emissions from wild fires and prescribed burns.

As part of the Tahoe Prescribed Fires and Nutrient Emission Experiment (TPFNEE), laboratory-controlled burning experiments were conducted with fuels prepared at different moisture levels. The experiments emphasized shrubs and downed materials that were subject to both prescribed and wild fires. This paper documents changes in emission factors of $\mathrm{C}$ and $\mathrm{N}$ species as a function of fuel moisture content. Based on continuous and time-integrated measurements, it also examines the emission mechanisms needed for process-based emission models. The Tahoe basin is a typical alpine forest in North America. Decades of fire suppression resulted in large biomass accumulation in this region. Prescribed burning is considered as an option for fuel reduction, and TPFNEE was tasked to provide a critical assessment on the environmental impact of such practices.

\section{Methods}

Biomass and soil samples were collected in Incline Village, Nevada, northeast of the Lake Tahoe Basin, in spring 2008 from two plots that were scheduled for prescribed burning by the United States Forest Service (USFS). Within each of the plots, downed materials in a $20 \times 20 \mathrm{~cm}^{2}$ area, $5 \mathrm{~cm}$ deep bulk volume were picked up from the forest floor at 12 randomly selected coordinates for a total of 6-8 kilograms of materials. These materials were then segregated into: 1) litter (the surface layer which is not in an advanced stage of decomposition, typically consisting of freshly fallen and dried leaves, needles, twigs, stems, bark, and fruits; 2) duff (the layer dominated by partially to fully decaying leaves and branches); and 3) topsoil (mixture of mineral soil, humus, and/or degraded organic material). Topsoil was examined because Murphy et al. (2006) found that wild fires nearly deplete $\mathrm{C}$ and $\mathrm{N}$ in soils. Common aboveground shrubs were also collected and separated in the laboratory into leaves and stems of different diameters. Acquired samples were stored in sealed polyethylene bags under refrigeration $\left(<4^{\circ} \mathrm{C}\right)$.

The field moisture content of each sample was quantified by drying a small portion of it at $85^{\circ} \mathrm{C}$ and measuring the weight loss after $24 \mathrm{~h}$. Litter, duff, and soil showed moisture contents between 1-10\% of dry mass, with median values of $3.5 \%, 5.0 \%, 3.8 \%$, respectively. Moisture contents of aboveground shrub samples (i.e., Bitterbrush, Green Leaf Manzanita, Huckleberry Oak, and Squaw Carpet) were higher, ranging from $6.5-50.0 \%$ for leaves and $9.3-49.0 \%$ for stems. Fractions of $\mathrm{C}$ and $\mathrm{N}$ in the dried mass were determined by CHNS-O analysis (Thermo EA1110-CHNS-O elemental analyzer, Thermo Nicolet Corporation, Waltham, USA).

To prepare fuels for desired/with different moisture contents, individual litter, duff, and soil samples from different locations were first homogenized and air dried for a week at $30 \%$ relative humidity. Calculated amounts of water were added into these samples to achieve fuels with moisture contents of 10 or $20 \%$ of dry mass. Shrub leaf and stem samples were also composited, and either air dried or soaked in water for 24 to $96 \mathrm{~h}$. The fuel moisture content, determined from the weight loses of small fractions of samples, increased over time and gradually reached saturation (Fig. 1). Dry, 24-h soaked, and 96-h soaked biomass were used for the burning experiments. Table 1 shows the fuels and moisture levels examined in this study. The two wet moisture levels (II \& III) simulated natural fuels of relatively high moisture contents. Two replicate burns were conducted for each fuel-moisture combination.

Figure 2 shows the combustion facility and measurement suite. Fuels were loaded on a uniformly-heated hotplate $\left(25 \times 25 \mathrm{~cm}^{2}\right)$ with adjustable temperatures up to $500^{\circ} \mathrm{C}$. Fuels were weighed before and after the experiment. Fuel loads were $23-69 \mathrm{~g}$ per burn. The hotplate kept fuels warm throughout the experiment to simulate large scale burns where environmental temperatures could be much higher than those in the laboratory without a heater. The hotplate was located in a $60-\mathrm{cm}$ diameter fire pit. Horizontal air flow was kept calm, and most of the smoke was vented through the chimney with an exhaust fan. Fuels were placed on the hotplate (maintained at $450^{\circ} \mathrm{C}$ ) for $\sim 30 \mathrm{~s}$ before starting an electric hot-air gun (Looft Lighter) to ignite them. Dry fuels were ignited within seconds, while it generally required application of hot air $\left(\sim 600^{\circ} \mathrm{C}\right)$ for $1-2$ min to ignite high moisture fuels. Some wet fuels required additional use of the hot air gun for several minutes to sustain combustion after ignition. The hot air gun avoided interference from emissions of combustion-based igniter (e.g., propane torch).

The smoke sampling probe consisted of 2-inch $(5.08 \mathrm{~cm})$ diameter conductive tubing stretching from the top of chimney, about $1.5 \mathrm{~m}$ above the fuels, to a mixing plenum (Fig. 2). Plumes generally equilibrated with ambient temperatures in 


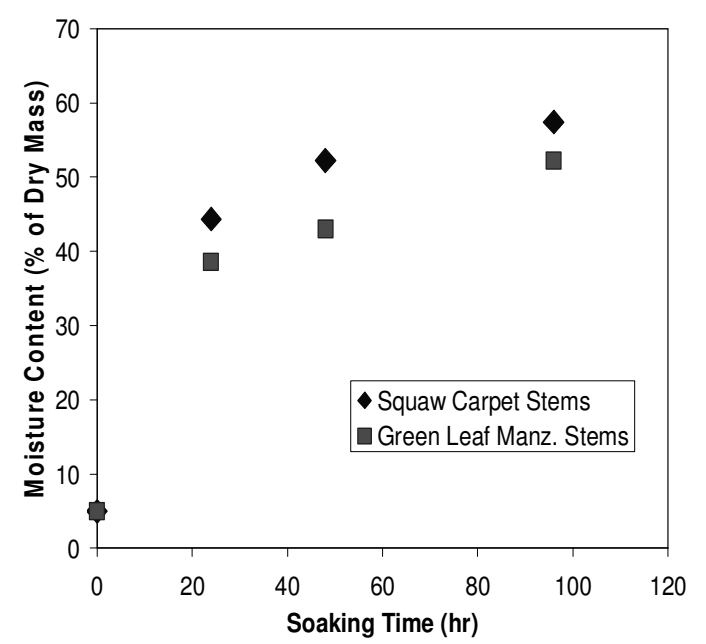

Fig. 1. Examples of fuel moisture content, starting air dried $(0 \mathrm{~h})$, as a function of time soaking in water. Excess water was drained before the measurement of moisture content.

the plenum. Through two size-cut cyclones, $\mathrm{PM}_{2.5}$ (particles with aerodynamic diameter $<2.5 \mu \mathrm{m}$ ) were sampled onto 1 ) a Teflon-membrane filter (for $\mathrm{PM}_{2.5}$ mass and elements) with a calcium carbonate impregnated cellulous backup filter (for sulfur dioxide $\left[\mathrm{SO}_{2}\right]$ ) and 2) a quartz-fiber filter (for organic carbon $[\mathrm{OC}]$ and elemental carbon [EC] by the IMPROVE_A protocol (Chow et al., 2007a) and water-soluble ions) with citric acid impregnated cellulous backup filter (for $\mathrm{NH}_{3}$ ). The analytical methods for filter samples are the same as described in Chow (1995) and Chow et al. (2004). Lower quantifiable limits (LQLs) were established with dynamic blanks through the same sampling channels but in the absence of combustion. Measurement precision is $<10 \%$ for concentrations greater than 10 times the LQLs. Additionally, portions of quartz-fiber filters were submitted to the CHNS-O analyzer for quantifying total $\mathrm{C}$ (TC), $\mathrm{N}$ (TN), and hydrogen (TH) in $\mathrm{PM}_{2.5}$. TC by CHNS-O analysis agrees with $\mathrm{OC}+$ EC by IMPROVE_A within $\pm 8 \%$.

An Electric Low Pressure Impactor (ELPI) was used to measure particle size and number concentrations in real time. The ELPI has 12 stages covering an aerodynamic size range of $10 \mathrm{~nm}$ to $10 \mu \mathrm{m}$. Size retrieval followed the algorithm developed by Marjamäki et al. (2005), which is shown to give accurate size distributions for particles smaller than $3 \mu \mathrm{m}$ (Pagels et al., 2005). Through Teflon tubing from the plenum and downstream of a Teflon particle filter (Fig. 1), several gaseous species were continuously monitored with a nondispersive infrared $\mathrm{CO}_{2} / \mathrm{H}_{2} \mathrm{O}$ analyzer (LI-840, LiCor Biosciences, Lincoln, NE), an extractive Fourier Transform Infrared (FTIR) Spectrometer (Midac, Costa Mesa, CA, for $\mathrm{CO}$ ), and research-grade $\mathrm{NO}_{\mathrm{x}}$ and $\mathrm{NH}_{3}$ analyzers (TECO 42 and $17 \mathrm{C}$, Thermo Scientific, Waltham, MA). These analyzers were calibrated against standards traceable to the National

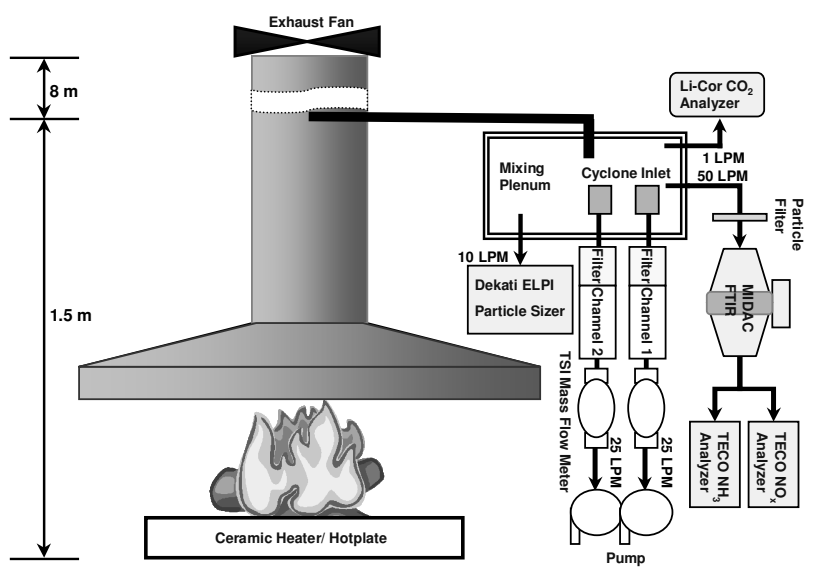

Fig. 2. Schematic of the controlled burning experiment configurations.

Institute of Standard and Technology before and after the experiments. The detection ranges (10-s average) were $0.001-$ $10,0.1-3000$, and 1-10000 ppmv for the TECO, Li-Cor, and Midac analyzers, respectively. The precision of gas measurements is estimated to be $<5 \%$ if they are within the instrumental detection range. All our experiments met the condition.

Since the experimental setup sampled a small portion of smoke plumes, production efficiencies of gaseous and particulate species (per unit fuel consumption) were calculated using a carbon balance approach (Andreae and Merlet, 2001). The concentration ratio of a measured species over grand total carbon (GTC) released from a burn defines the emission factor $(\mathrm{EF})$ of that species in gram per kilogram of carbon burned, which can be scaled to gram per kilogram of fuel consumed with known carbon content of the fuel. GTC includes $\mathrm{C}$ in $\mathrm{CO}_{2}, \mathrm{CO}$, and $\mathrm{PM}_{2.5}$. Volatile organic compounds (VOCs) including $\mathrm{CH}_{4}$ were not measured, though under most circumstances VOCs are minor contributors, compared to $\mathrm{CO}_{2}$ and $\mathrm{CO}$, in the carbon budget of emissions $(<5 \%)$. Natural variability of EFs, according to replicate burns, usually exceeds the EF uncertainties estimated from the analytical precision. Table 1 shows the average and standard deviation of fuel-specific EFs, while Fig. 3 illustrates their dependence on the fuel moisture content. All leaf and stem burns have been combined in Fig. 3 to increase the number of replicate measurements.

\section{Results and discussion}

Dry and wet biomass fuels showed distinct fire behaviors. Dry fuels were ignited easily by the hot air and flames quickly spread over the fuel. Residues after the burn were small except for the duff composite, for which only half of the dry mass was combusted (Table 1). The duff sample likely contained substantial mineral material, as its carbon 
Table 1. Time-integrated combustion efficiency (CE) and emission factors ${ }^{\mathrm{a}}$ for major $\mathrm{C}$ and $\mathrm{N}$ species as well as $\mathrm{PM}_{2.5}$ from controlled burning experiments.

\begin{tabular}{|c|c|c|c|c|c|c|c|c|c|c|}
\hline \multicolumn{2}{|c|}{ Fuel Type $\rightarrow$} & \multicolumn{3}{|c|}{ Downed Material } & \multicolumn{6}{|c|}{ Aboveground Shrub } \\
\hline \multirow{2}{*}{\multicolumn{2}{|c|}{ Moisture/Parameter }} & \multicolumn{3}{|c|}{ Composite } & \multicolumn{2}{|c|}{ Bitterbrush } & \multicolumn{2}{|c|}{ Manzanita } & \multicolumn{2}{|c|}{ Squaw Carpet } \\
\hline & & Litter & Duff & Soil & Leaves & Stems & Leaves & Stems & Leaves & Stems \\
\hline \multirow{12}{*}{$\begin{array}{l}\text { Moisture } \\
\text { Level I (Dry }{ }^{\mathrm{e}} \text { ) }\end{array}$} & Carbon $\%^{b}$ & $50 \%$ & $32 \%$ & $3 \%$ & $52 \%$ & $48 \%$ & $49 \%$ & $48 \%$ & $47 \%$ & $50 \%$ \\
\hline & Burned $\%^{\mathrm{c}}$ & $92 \%$ & $52 \%$ & $9 \%$ & $92 \%$ & $81 \%$ & $90 \%$ & $98 \%$ & $83 \%$ & $93 \%$ \\
\hline & $\mathrm{CE}$ & $0.94 \pm 0.01$ & $0.92 \pm 0.02$ & $0.86 \pm 0.02$ & $0.93 \pm 0.01$ & $0.94 \pm 0.00$ & $0.91 \pm 0.01$ & $0.94 \pm 0.00$ & $0.92 \pm 0.01$ & $0.92 \pm 0.00$ \\
\hline & $\mathrm{CO}^{\mathrm{f}}$ & $126.2 \pm 12.7$ & $140.6 \pm 27.3$ & $297.3 \pm 48.2$ & $112.6 \pm 30.3$ & $127.4 \pm 8.8$ & $113.2 \pm 43.5$ & $128.4 \pm 6.7$ & $144.5 \pm 22.3$ & $162.1 \pm 8.9$ \\
\hline & $\mathrm{OC}$ & $2.5 \pm 0.2$ & $(9.3 \pm 6.7)$ & $14.9 \pm 4.4$ & $9.1 \pm 1.8$ & $6.4 \pm 2.0$ & $21.2 \pm 7.9$ & $5.5 \pm 0.6$ & $11.3 \pm 0.2$ & $4.7 \pm 0.1$ \\
\hline & $\mathrm{EC}$ & $4.6 \pm 0.3$ & $5.7 \pm 0.1$ & $0.7 \pm 0.2$ & $15.4 \pm 2.7$ & $2.9 \pm 0.3$ & $15.9 \pm 3.9$ & $2.0 \pm 0.4$ & $8.1 \pm 0.8$ & $2.5 \pm 0.5$ \\
\hline & $\mathrm{PM}_{2.5}$ & $8.1 \pm 0.9$ & $(18.3 \pm 10.2)$ & N.D. & $27.1 \pm 5.8$ & $13.0 \pm 3.9$ & $47.5 \pm 14.1$ & $8.7 \pm 0.4$ & $25.3 \pm 3.2$ & $14.5 \pm 1.1$ \\
\hline & $\mathrm{NO}_{\mathrm{x}}^{\mathrm{f}}$ & $5.9 \pm 0.3$ & $4.9 \pm 0.9$ & $0.9 \pm 0.2$ & $9.1 \pm 2.8$ & $9.1 \pm 1.0$ & $7.1 \pm 3.0$ & $5.4 \pm 1.0$ & $7.7 \pm 1.5$ & $10.5 \pm 0.8$ \\
\hline & $\mathrm{NH}_{3}$ & $(1.3 \pm 1.1)$ & $(3.7 \pm 2.4)$ & $(11.5 \pm 6.1)$ & $7.7 \pm 2.4$ & $3.4 \pm 0.6$ & $4.0 \pm 1.6$ & $1.9 \pm 0.8$ & $6.8 \pm 1.6$ & $5.6 \pm 0.1$ \\
\hline & $\mathrm{NO}_{3}^{-}$ & $0.04 \pm 0.01$ & $(0.03 \pm 0.02)$ & N.D. & $0.05 \pm 0.01$ & $0.12 \pm 0.00$ & $0.16 \pm 0.04$ & $0.12 \pm 0.00$ & $0.07 \pm 0.00$ & $0.09 \pm 0.02$ \\
\hline & $\mathrm{NH}_{4}^{+}$ & $0.05 \pm 0.01$ & $0.06 \pm 0.03$ & N.D. & $0.04 \pm 0.00$ & $0.04 \pm 0.01$ & $0.04 \pm 0.00$ & $0.03 \pm 0.00$ & $0.05 \pm 0.00$ & $0.08 \pm 0.00$ \\
\hline & OPN & $(0.24 \pm 0.19)$ & $(0.44 \pm 0.35)$ & $(0.31 \pm 0.23)$ & $0.40 \pm 0.11$ & $0.31 \pm 0.12$ & $0.47 \pm 0.21$ & $0.09 \pm 0.03$ & $0.45 \pm 0.04$ & $0.28 \pm 0.01$ \\
\hline \multirow{12}{*}{$\begin{array}{l}\text { Moisture } \\
\text { Level II }\end{array}$} & Moisture $^{\mathrm{d}}$ & $10 \%$ & $10 \%$ & $10 \%$ & $73 \%$ & $39 \%$ & $40 \%$ & $39 \%$ & $48 \%$ & $44 \%$ \\
\hline & Burned $\%$ c & $72 \%$ & $47 \%$ & $10 \%$ & $88 \%$ & $66 \%$ & $73 \%$ & $53 \%$ & $69 \%$ & $92 \%$ \\
\hline & $\mathrm{CE}$ & $0.79 \pm 0.06$ & $0.70 \pm 0.07$ & $0.80 \pm 0.06$ & $0.88 \pm 0.01$ & $0.82 \pm 0.06$ & $0.72 \pm 0.03$ & $0.86 \pm 0.11$ & $0.67 \pm 0.09$ & $0.86 \pm 0.06$ \\
\hline & $\mathrm{CO}^{\mathrm{f}}$ & $253.2 \pm 59.8$ & $444.9 \pm 68.1$ & $431.4 \pm 143.8$ & $113.2 \pm 42.4$ & $261.3 \pm 44.0$ & $(97.5 \pm 76.7)$ & $107.1 \pm 2.4$ & $(77.7 \pm 57.7)$ & $(108.1 \pm 96.0)$ \\
\hline & $\mathrm{OC}$ & $99.8 \pm 34.9$ & $110.9 \pm 41.5$ & $17.5 \pm 1.0$ & $66.1 \pm 9.9$ & $(66.6 \pm 36.1)$ & $236.0 \pm 62.4$ & $(62.8 \pm 64.1)$ & $292.2 \pm 115.1$ & $92.6 \pm 18.4$ \\
\hline & $\mathrm{EC}$ & $5.2 \pm 0.3$ & $1.0 \pm 0.1$ & $1.5 \pm 0.5$ & $(7.3 \pm 4.0)$ & $3.7 \pm 0.7$ & $5.6 \pm 1.1$ & $(2.3 \pm 1.2)$ & $8.5 \pm 3.2$ & $2.6 \pm 0.3$ \\
\hline & $\mathrm{PM}_{2.5}$ & $160.5 \pm 56.2$ & $143.9 \pm 62.2$ & N.D. & $96.9 \pm 18.3$ & $(119.3 \pm 73.7)$ & $214.9 \pm 84.1$ & $(94.9 \pm 91.3)$ & $270.8 \pm 68.4$ & $109.6 \pm 32.7$ \\
\hline & $\mathrm{NO}_{\mathrm{x}}^{\mathrm{f}}$ & $6.4 \pm 1.5$ & $6.7 \pm 1.4$ & $2.8 \pm 0.8$ & $9.9 \pm 4.0$ & $13.0 \pm 3.1$ & $(2.2 \pm 2.9)$ & $2.9 \pm 1.2$ & $(4.0 \pm 5.4)$ & $(10.7 \pm 7.9)$ \\
\hline & $\mathrm{NH}_{3}$ & $4.3 \pm 1.7$ & $(26.7 \pm 14.0)$ & $24.7 \pm 6.6$ & $10.2 \pm 1.5$ & $10.7 \pm 0.9$ & $10.0 \pm 0.5$ & $3.8 \pm 0.5$ & $11.9 \pm 4.1$ & $11.0 \pm 5.4$ \\
\hline & $\mathrm{NO}_{3}^{-}$ & $0.17 \pm 0.00$ & $0.13 \pm 0.01$ & N.D. & $0.23 \pm 0.02$ & $0.20 \pm 0.02$ & $0.08 \pm 0.03$ & $0.08 \pm 0.01$ & $0.23 \pm 0.04$ & $0.20 \pm 0.01$ \\
\hline & $\mathrm{NH}_{4}^{+}$ & $0.24 \pm 0.04$ & $0.15 \pm 0.01$ & N.D. & $0.10 \pm 0.00$ & $(0.03 \pm 0.02)$ & $0.31 \pm 0.09$ & $(0.05 \pm 0.06)$ & $0.28 \pm 0.11$ & $0.06 \pm 0.01$ \\
\hline & OPN & $1.62 \pm 0.59$ & $3.57 \pm 1.50$ & $0.99 \pm 0.26$ & $2.03 \pm 0.05$ & $1.39 \pm 0.68$ & $4.4 \pm 1.42$ & $(1.07 \pm 1.33)$ & $7.70 \pm 3.28$ & $2.17 \pm 0.46$ \\
\hline \multirow{12}{*}{$\begin{array}{l}\text { Moisture } \\
\text { Level III }\end{array}$} & Moisture $^{\mathrm{d}}$ & $20 \%$ & $20 \%$ & $20 \%$ & $84 \%$ & $57 \%$ & $60 \%$ & $52 \%$ & $66 \%$ & $57 \%$ \\
\hline & Burned $\%^{\mathrm{c}}$ & $80 \%$ & $45 \%$ & $9 \%$ & $86 \%$ & $78 \%$ & $68 \%$ & $92 \%$ & $65 \%$ & $90 \%$ \\
\hline & $\mathrm{CE}$ & $0.74 \pm 0.10$ & $0.69 \pm 0.07$ & $0.82 \pm 0.01$ & $0.51 \pm 0.07$ & $0.84 \pm 0.04$ & $0.62 \pm 0.09$ & $0.87 \pm 0.00$ & $0.72 \pm 0.01$ & $0.88 \pm 0.08$ \\
\hline & $\mathrm{CO}^{\mathrm{f}}$ & $313.6 \pm 105.8$ & $407.6 \pm 29.2$ & $357.7 \pm 15.9$ & $215.6 \pm 31.1$ & $216.8 \pm 60.4$ & $134.2 \pm 43.5$ & $188.5 \pm 25.1$ & $142.6 \pm 22.3$ & $(133.1 \pm 102.6)$ \\
\hline & $\mathrm{OC}$ & $116.6 \pm 48.8$ & $131.1 \pm 59.2$ & $22.1 \pm 0.8$ & $393.6 \pm 54.1$ & $67.8 \pm 11.1$ & $315.3 \pm 111.1$ & $43.1 \pm 5.8$ & $210.4 \pm 20.2$ & $(61.5 \pm 39.7)$ \\
\hline & $\mathrm{EC}$ & $(7.6 \pm 4.9)$ & $1.1 \pm 0.2$ & $2.3 \pm 0.9$ & $5.3 \pm 0.5$ & $3.6 \pm 0.1$ & $7.7 \pm 1.3$ & $2.6 \pm 1.0$ & $4.8 \pm 0.0$ & $2.7 \pm 0.7$ \\
\hline & $\mathrm{PM}_{2.5}$ & $179.9 \pm 54.7$ & $208.9 \pm 56.2$ & N.D. & $768.7 \pm 43.2$ & $99.5 \pm 4.4$ & $493.8 \pm 231.9$ & $61.5 \pm 3.8$ & $387.2 \pm 31.1$ & $129.1 \pm 43.5$ \\
\hline & $\mathrm{NO}_{\mathrm{x}}^{\overline{\mathrm{f}}}$ & $8.4 \pm 2.5$ & $3.8 \pm 0.2$ & $5.4 \pm 0.1$ & $9.6 \pm 2.0$ & $7.5 \pm 0.5$ & $(2.7 \pm 2.0)$ & $4.7 \pm 0.5$ & $6.4 \pm 2.2$ & $9.1 \pm 2.3$ \\
\hline & $\mathrm{NH}_{3}$ & $5.3 \pm 0.4$ & $17.7 \pm 5.9$ & $(24.5 \pm 18.0)$ & $19.1 \pm 1.4$ & $10.9 \pm 1.8$ & $10.1 \pm 0.4$ & $3.8 \pm 0.0$ & $9.5 \pm 0.8$ & $(9.7 \pm 4.9)$ \\
\hline & $\mathrm{NO}_{3}^{-}$ & $0.20 \pm 0.05$ & $0.09 \pm 0.03$ & N.D. & $0.28 \pm 0.11$ & $0.18 \pm 0.02$ & $0.12 \pm 0.00$ & $0.11 \pm 0.01$ & $0.14 \pm 0.03$ & $(0.13 \pm 0.08)$ \\
\hline & $\mathrm{NH}_{4}^{+}$ & $0.30 \pm 0.11$ & $0.15 \pm 0.06$ & N.D. & $0.32 \pm 0.11$ & $0.06 \pm 0.01$ & $0.42 \pm 0.14$ & $0.07 \pm 0.01$ & $0.18 \pm 0.00$ & $(0.05 \pm 0.03)$ \\
\hline & OPN & $1.59 \pm 0.56$ & $3.36 \pm 1.40$ & $0.60 \pm 0.07$ & $11.83 \pm 0.53$ & $1.59 \pm 0.39$ & $4.32 \pm 1.52$ & $0.66 \pm 0.04$ & $4.43 \pm 0.36$ & $(1.33 \pm 0.76)$ \\
\hline
\end{tabular}

a In $\mathrm{g} / \mathrm{kgC}$ (g per kilogram of carbon burned). Values are based on the average and standard deviation of two replicate burns. N.D. indicates the species are below detection limit. Emission factors with higher variability (average/standard deviation $<2$ ) are shown in bracket.

$\mathrm{b}$ Percentage of carbon in dry fuels.

c Combined percentage of dry fuel burned.

${ }^{\mathrm{d}}$ Fuel moisture content in percentage of dry mass.

e Moisture content $<5 \%$.

${ }^{\mathrm{f}}$ Not filter-based measurements.

content $(32 \%)$ was lower than the nominal value (i.e., $45-$ $50 \%$ ) for biomass (McMeeking et al., 2009). It took much longer for wet fuels to ignite when they were heated by the same hot air. Smoke was visible before ignition. Flaming periods were relatively short, followed by prolonged smoldering combustion. Wet fuels left more and variable amounts of unburnable residues than dry fuels. For soil, flames were absent throughout the experiments, and only $9-10 \%$ of the dry mass was consumed, regardless of moisture content.
Particles from each individual burn were collected on a single set of Teflon and quartz-fiber filters that yielded burnaverage chemical compositions. For consistency, all continuous measurements were baseline subtracted and integrated over the filter sampling period. $\mathrm{NH}_{3}$ from the TECO $17 \mathrm{C}$ correlated reasonably with those of filters $(r=0.83)$, but the TECO $17 \mathrm{C}$ values were lower by an average of $21 \%$ and as much as $80 \%$. This possibly results from the loss of $\mathrm{NH}_{3}$ in the Teflon sampling tubing and to the pre-analyzer particle filter (e.g., Mukhtar et al., 2003). EF calculations 
(i.e., Table 1) were therefore based on filter measurements which deployed much shorter/larger diameter tubing from the plenum. $\mathrm{CO}_{2}, \mathrm{CO}$, and $\mathrm{NO}_{\mathrm{x}}$ adsorption on Teflon surface are generally negligible.

\subsection{Time-integrated carbon measurement}

Combustion efficiency (CE), defined as the fraction of $\mathrm{C}$ emissions in the form of $\mathrm{CO}_{2}$, best indicates the relative importance of flaming (high CE) and smoldering (low CE) phases (Sinha et al., 2004; Janhäll et al., 2010). CE was $>0.9$ for all dry fuels (except soil) and was $<0.9$ for all wet fuels in this study (Table 1). In general, wet duff/leaves produced lower CEs than wet litter/stems, though there are no apparent differences in CEs between the two wet moisture levels (II and III). $\mathrm{CO}$ often constitutes most of the non- $\mathrm{CO}_{2}$ carbon from biomass burning (Yokelson et al., 1996; Andreae and Merlet, 2001; McMeeking et al., 2009). For fuels with high moisture contents, however, particulate carbon approached or exceeded the carbon in $\mathrm{CO}$ emissions. The sum of $\mathrm{OC}$ and EC (moisture level III, Table 1) exceeds 2-4 times the carbon from CO for three stem burns and is $57-113 \%$ of CO carbon for the rest of burns except soil.

Thermal/optical analysis indicates that most of the particulate carbon is OC. The increasing $\mathrm{PM}_{2.5}$ and OC EFs with fuel moisture content are clear for leaf combustion (and to a less degree for litter, duff, and stem, Fig. 3). This likely reflects an enhanced primary process converting plant material to OC, since the experimental setup does not allow plumes to age sufficiently for secondary OC formation. Soil contains little biomass, and the influence of soil moisture on OC emissions is limited. Although only leaf and duff burns show EC EFs to decrease with increasing fuel moisture content, the EC fraction in TC ranges from 0.01 to 0.68 with all the highest values found from burning dry biomass. This is consistent with EC being generated from flaming combustion that intensifies with dry fuels. From such burns, Charkrabarty et al. (2006) identified soot-based particles similar to those from diesel engines.

The TH/TC ratio increases with the OC fraction in TC (Fig. 4), which corroborates the dominance of hydrocarbon and elemental $\mathrm{C}$ in the (operationally-defined) $\mathrm{OC}$ and EC, respectively. For 17 biomass burns in which $\mathrm{OC} / \mathrm{TC}>0.97$ (i.e., low to no $\mathrm{EC}$ ), the $\mathrm{TH} / \mathrm{TC}$ ratio averages at $0.13 \pm 0.02$. Considering TH/TC ratios of $0.167,0.139$, and 0.108 for sugar $\left[\left(\mathrm{CH}_{2} \mathrm{O}\right)_{n}\right]$, cellulose $\left[\left(\mathrm{C}_{6} \mathrm{H}_{10} \mathrm{O}_{5}\right)_{n}\right]$, and lignin $\left[\left(\mathrm{C}_{10} \mathrm{H}_{13} \mathrm{O}_{3}\right)_{n}\right]$, respectively, the OC may result from decomposition of cellulose, which is the most abundant organic polymer in biomass (Gani and Naruse, 2007).

Particles from wet fuel combustion often appear yellowish to brownish on filters and in water extracts, in contrast to a black appearance from dry fuels (Andreae and Gelencser, 2006). A two-wavelength (370 and $880 \mathrm{~nm})$ filter transmittance instrument (OT21, Magee Scientific Co, Berkeley, CA) was used to examine the loaded Teflon filters for wavelength-

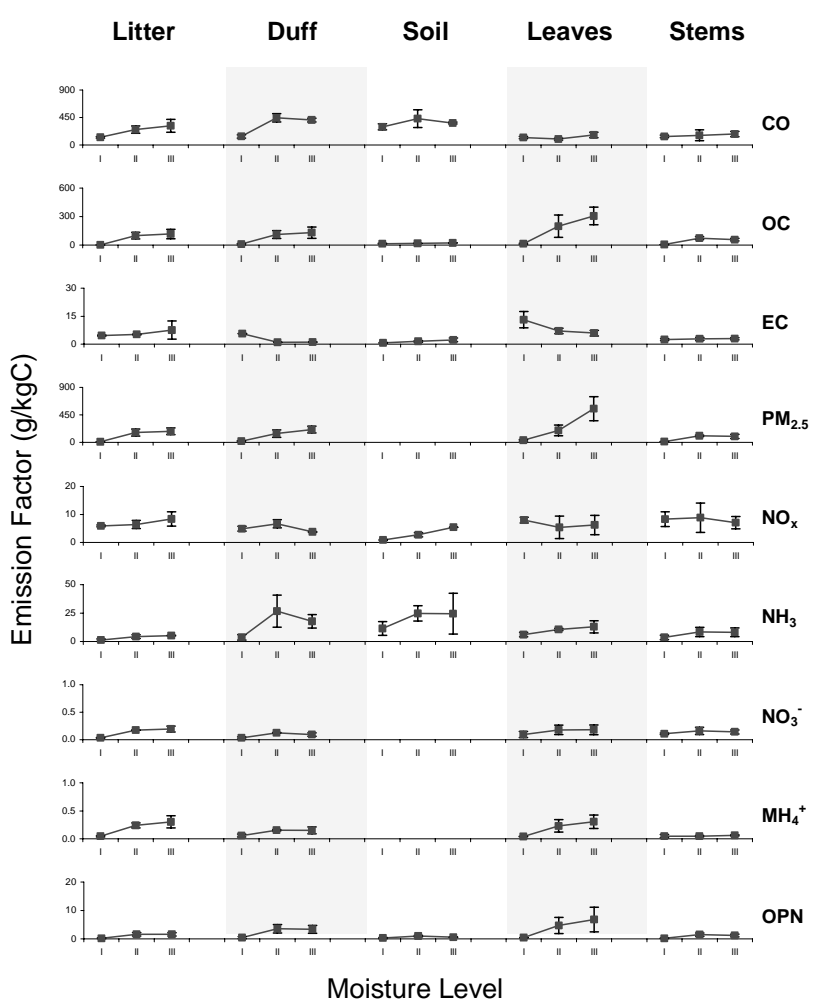

Fig. 3. Emission factors, by fuel type, as a function of fuel moisture level, based on data presented in Table 1 (all the leaf and stem data have been combined).

dependent absorption of particles. The absorption exponent (AE) was calculated by

$\mathrm{AE}=-\frac{\ln \left(\mathrm{ATN}_{370}\right)-\ln \left(\mathrm{ATN}_{880}\right)}{\ln (370)-\ln (880)}$

where ATN is the filter attenuation used as a surrogate for light absorption (Moosmüller et al., 2009). The increasing AE with higher OC/TC ratio (Fig. 4) shows that OC absorption is skewed toward shorter wavelengths than EC absorption, a principle characteristic of brown carbon $(\mathrm{BrC})$. Ultraviolet (UV) absorption by such $\mathrm{BrC}$ can be comparable to that by black carbon (Kirchstetter et al., 2004). Though levoglucosan $\left(\mathrm{C}_{6} \mathrm{H}_{10} \mathrm{O}_{5}\right)$ is regarded as the main product from cellulous decomposition during biomass burning and has been used as a marker for apportioning biomass burning contributions to ambient $\mathrm{PM}_{2.5}$ (Simoneit et al., 1999; Rinehart et al., 2006; Chow et al., 2007b), it is colorless. Formation of $\mathrm{BrC}$ from biomass burning must involve not only thermal decomposition but also oxidation and/or other reactions in the plumes.

\subsection{Time-entegrated nitrogen measurement}

Lobert et al. (1990) suggested that $\mathrm{NO}_{\mathrm{x}}$ accounts for most of fuel $\mathrm{N}$ detected in biomass burning plumes, followed by 


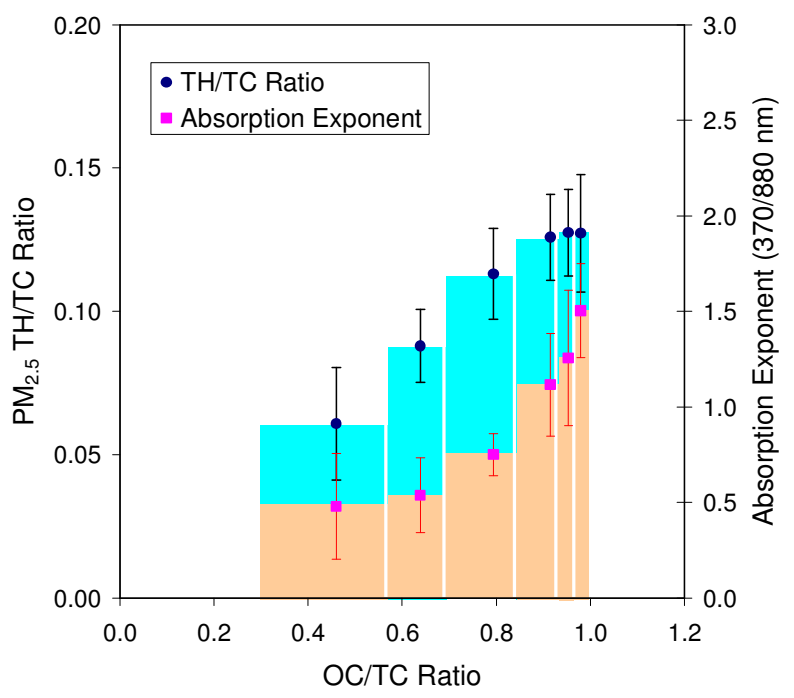

Fig. 4. Conditional means of TH/TC ratio and absorption exponent of biomass-burning $\mathrm{PM}_{2.5}$ as a function of $\mathrm{OC}$ fraction in TC. The symbols correspond to six groups of samples with OC/TC ratio of 1) $0.3-0.575$, 2) $0.575-0.7,3) 0.7-0.85$, 4) $0.85-0.94,5) 0.94-0.97$, and 6) $0.97-1$. Soil combustion samples were excluded from this analysis.

$\mathrm{NH}_{3}$, hydrogen cyanide $(\mathrm{HCN}), \mathrm{N}_{2} \mathrm{O}$, and nitriles. This is the case for some dry biomass (i.e., litter and stems) burns in this study (Table 1). In other cases $\mathrm{NH}_{3}$ carries the most nitrogen, while $\mathrm{N}_{2} \mathrm{O}$ is below the detection limit and HCN not quantified. Particulate N, which was not previously addressed in Lobert et al. (1990), is substantial from wet fuel combustion emissions. Only a small fraction of the particulate $\mathrm{N}$ can be attributable to water soluble $\mathrm{NO}_{3}^{-}$and $\mathrm{NH}_{4}^{+}$. Other particulate nitrogen (OPN, particulate $\mathrm{N}$ minus $\mathrm{N}$ from $\mathrm{NO}_{3}^{-}$and $\mathrm{NH}_{4}^{+}$) EFs increase with fuel moisture content (Fig. 3) and are particularly high ( $>2 \mathrm{~g} / \mathrm{kgC}$ and up to $75 \%$ of $\mathrm{N}$ in $\mathrm{NH}_{3}$ ) when burning wet duff and leaves (see moisture level II and III in Table 1). The fact that OPN and to a lesser extent $\mathrm{NH}_{3}$ EFs are anti-correlated with CE for all fuel types, including soil, indicates that they are favored products during smoldering combustion. This is not the case for $\mathrm{NO}_{\mathrm{x}}$.

It is possible that some $\mathrm{N}$-containing gases, such as $\mathrm{NH}_{3}$, mixed with $\mathrm{PM}_{2.5}$ in plumes and/or on filters and was measured as OPN. $\mathrm{NH}_{3}$ adsorbed on quartz-fiber filters should be detected as $\mathrm{NH}_{4}^{+}$under the current procedure (i.e., water extraction/automated colorimetry) while adsorption of other gases seems minor compared to the amounts of OPN observed. In addition, OPN is highly correlated with OC $(r=0.93$; slope $=0.022)$ for all biomass burns. This suggests that most OPN forms, along with OC, from the decomposition or pyrolysis of plant material and is in the form of organic nitrogen.

The nitrogen balance is evaluated by scaling N/GTC ratios in the combustion products to those in the fuels (Fig. 5). Bet- ter closure for wet fuels results, for the most part, from higher $\mathrm{NH}_{3}$ and OPN emissions. Nearly $100 \%$ of $\mathrm{N}$ was recovered from the wet litter composite and bitterbrush leaf burns. In other burns, however, substantial $\mathrm{N}$ was missing. Besides HCN and nitriles, Lobert et al. (1990) suggested that up to $50 \%$ of biomass $\mathrm{N}$ could end up becoming molecular nitrogen $\left(\mathrm{N}_{2}\right)$, which cannot be detected in open fires due to the large $\mathrm{N}_{2}$ fraction of the ambient air. Combustion experiments conducted in a closed chamber supplied with helium/oxygen air showed dominant $\mathrm{N}_{2}$ emissions from biomass burning, particularly during flaming combustion (Kuhlbusch et al., 1991). The mechanism of $\mathrm{N}_{2}$ formation is unclear, but such a process is inhibited during the relatively low-temperature smoldering phase, leaving $\mathrm{N}$ available for other species.

\subsection{Time-resolved measurement}

Continuous data provide additional insights into the biomass combustion process. Temporally-resolved dry- and wet-fuel combustion emissions are compared in Fig. 6a-b using Manzanita leaves as an example. $\mathrm{NH}_{3}$ concentrations in Fig. 6 (from TECO 17C) may be biased low as the averaged $\mathrm{NH}_{3}$ for these two burns are $\sim 10 \%$ lower than those measured on filters. They are only discussed qualitatively below.

The flaming phase for wet Manzanita leaves, consistent with the period with highly evaluated $\mathrm{CO}_{2}$ concentrations, was brief $(\sim 1 \mathrm{~min})$ relative to that of dry Manzanita leaves (3-4 min), though most of the $\mathrm{CO}_{2}$ and $\mathrm{NO}_{\mathrm{x}}$ were emitted during this phase. High temperatures in the flames provide sufficient thermal energy to break up plant organic matter into small fragments, producing $\mathrm{CH}_{4}$, VOCs, $\mathrm{CO}, \mathrm{NH}_{3}$, etc., which are subsequently oxidized to $\mathrm{CO}_{2}$ and $\mathrm{NO}_{\mathrm{x}}$. Dry fuels generate more intense flames, and therefore $\mathrm{CO}_{2}$ and $\mathrm{NO}_{\mathrm{x}}$ dominate the $\mathrm{C}$ and $\mathrm{N}$ species (except $\mathrm{N}_{2}$ ) in the smoke. From the end of flaming phase through the smoldering phase, thermal energy decreases and higher fractions of CO, VOCs, and $\mathrm{NH}_{3}$ are observed (e.g., Fig. 6a and Chen et al., 2007). For wet fuels, $\mathrm{NH}_{3}$ could be the dominant $\mathrm{N}$ species throughout the burn (e.g., Fig. 6b).

To investigate the emission of particle mass and the dominant size fraction, real-time ELPI particle size and number measurements were converted to particle volume concentration $\left(\mu \mathrm{m}^{3} / \mathrm{cm}^{3}\right)$ assuming spherical particles. The burnaveraged particle volume concentration correlates well with $\mathrm{PM}_{2.5}$ mass measured on Teflon filters $(r=0.90$, across all the samples) with a mass/volume slope of $1.01 \pm 0.08 \mathrm{~g} / \mathrm{cm}^{3}$.

For the two Manzanita leaf burns in Fig. 6, the timeresolved mean particle volume $\left(V_{\mathrm{p}}\right.$ in $\left.\mu_{\mathrm{m}}^{3}\right)$ was calculated from the ratio of particle volume and number concentrations. From $V_{\mathrm{p}}$ the particle volume mean (aerodynamic) diameter $\left(D_{\mathrm{v}}\right)$ was determined:

$D_{\mathrm{v}}=\left(\frac{6 V_{\mathrm{p}}}{\pi}\right)^{1 / 3}$ 


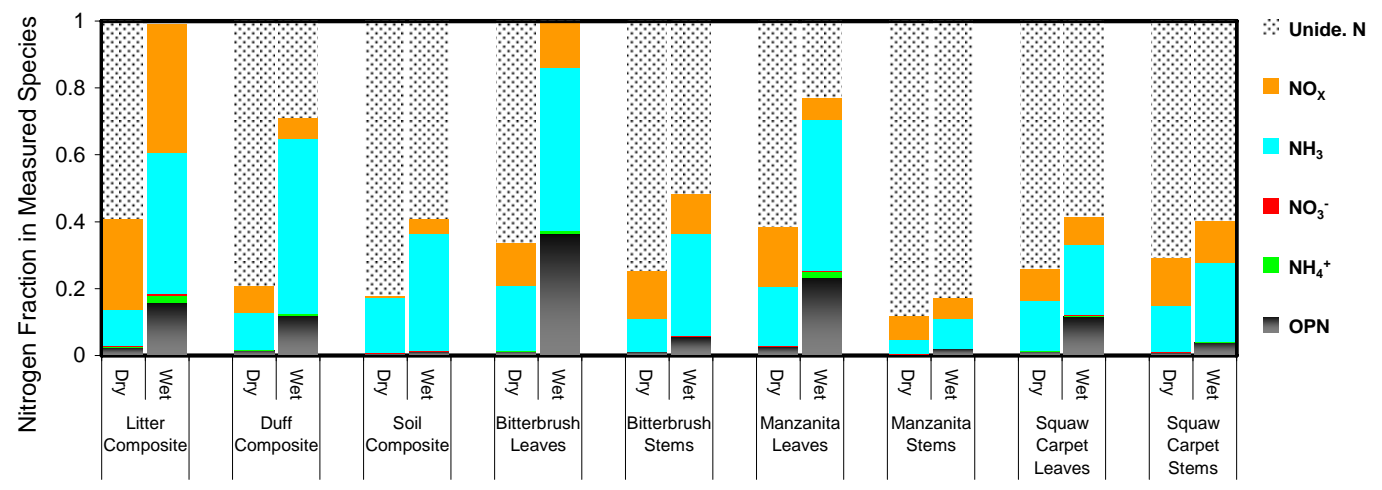

Fig. 5. Nitrogen balance with respect to fuel nitrogen content, determined from N/C ratios in smoke plumes and in fuels. Unidentified N (Unide. $\mathrm{N}$ ) is the fuel $\mathrm{N}$ that is not accounted for by measured species. Dry and wet fuels correspond to the Moisture Level I and III in Table 1 .

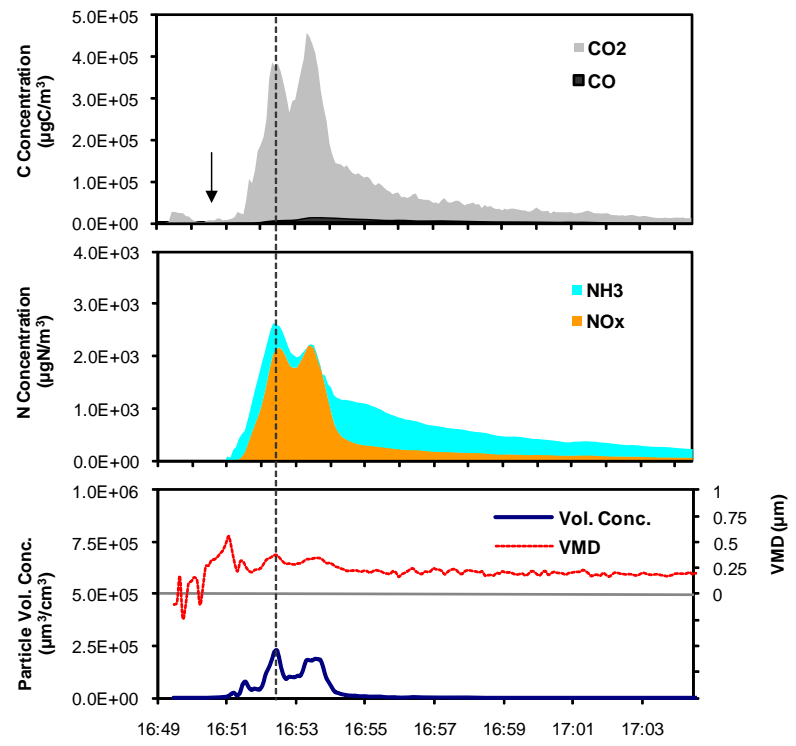

(a)

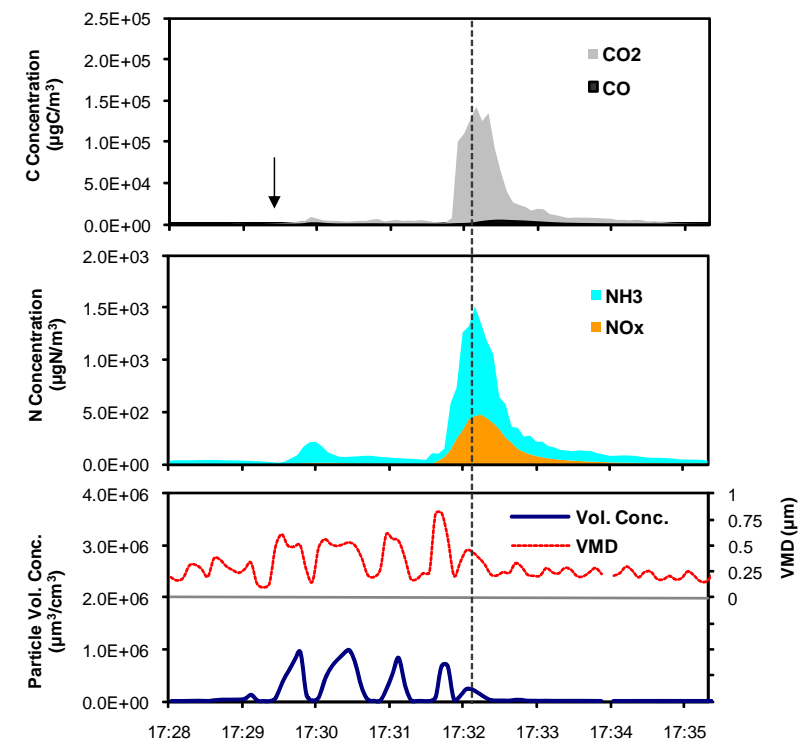

(b)

Fig. 6. Time series of gaseous (stacked area) and particulate concentrations during the burn of (a) dry and (b) wet Manzanita leaves. Particle size is represented by the volume mean diameter (VMD, i.e., $D_{\mathrm{v}}$ in the text). Arrows mark the start of hot-air igniter, and vertical dashed lines align the emission peaks.

Soot particles that mostly consist of EC are expected to form in the flames, and indeed peaks of particle volume concentration track those of $\mathrm{CO}_{2}$ well in Fig. 6a. $D_{\mathrm{v}}$ at the peaks is estimated to be $0.34-0.38 \mu \mathrm{m}$. Larger $D_{\mathrm{v}}$ up to $0.56 \mu \mathrm{m}$ are observed right before the flames start, which could be related to the initial breakdown of plant organic matter. These large particles, however, do not appear to account for substantial $\mathrm{PM}_{2.5}$ volume or mass from the dry fuel combustion. Reid et al. (2005) and Guyon et al. (2003) reported typical values of $D_{\mathrm{v}}$ ranging from $0.25-0.3 \mu \mathrm{m}$ for fresh smoke, but with some values as high as $0.5 \mu \mathrm{m}$.
Figure $6 \mathrm{~b}$ shows $\mathrm{NH}_{3}$ emissions, in the absence of $\mathrm{NO}_{\mathrm{x}}$ emission, during a prolonged heating/smoldering period before the wet Manzanita leaves were ignited. Unlike Fig. 6a, the ELPI recorded intense particle emissions during this preflame period, and this explains the much higher OC and OPN EFs from the wet fuels. $D_{\mathrm{v}}$ that correspond to each of the pre-flame peaks range from $0.56 \mu \mathrm{m}$ to $0.81 \mu \mathrm{m}$, with the largest $D_{\mathrm{v}}$ occurring right before the flame starts. These particles possibly consist of polyaccharides and/or its derivatives from the decomposition of cellulous. There is a smaller ELPI peak corresponding with the major $\mathrm{CO}_{2}$ hump (flaming phase). Particle size at this peak appears to be smaller, i.e., $D_{\mathrm{v}}=0.45 \mu \mathrm{m}$, but is more consistent with flaming soot particles observed in Fig. 6 a. 


\section{Conclusions}

To study the moisture effect on biomass burning emission, litter, duff, soil, and aboveground shrub vegetation had been collected from an alpine forest, prepared in the laboratory for three moisture levels (dry, partially wetted, and fully wetted), and submitted to laboratory-controlled combustion experiments. These experiments show that fuel moisture lowers the overall combustion efficiency, shortens the flaming phase, and prolongs smoldering period before flames start. EFs of $\mathrm{CO}, \mathrm{OC}, \mathrm{NH}_{3}$, and $\mathrm{OPN}$ increase with the fuel moisture content; the effect is generally larger for plant leaves and duff materials than for stems, litter, or soil. For high moisture leaves, emitted particulate $\mathrm{OC}$ can be as much as 4 times $\mathrm{C}$ in $\mathrm{CO}$ and $\mathrm{OPN}$ can be up to $75 \%$ of $\mathrm{N}$ in $\mathrm{NH}_{3}$. OPN and OC are found to highly correlate $(r=0.93)$.

$\mathrm{CO}_{2}$ and $\mathrm{CO}$ emissions are mostly associated with flaming combustion and post-flame smoldering, respectively, and so are $\mathrm{NO}_{\mathrm{x}}$ (flaming) and $\mathrm{NH}_{3}$ (smoldering). $\mathrm{N}_{2}$ emissions could be important especially during the flaming phase but cannot be quantified in open fires. The pre-flame smoldering of wet biomass mainly emits particles. These particles, with relatively large volume mean diameters (e.g., $>0.55 \mu \mathrm{m}$ ), most likely consist of OC and OPN from decomposition of plant materials. It appears that higher thermal energy in flames is required to break the plant materials further into simpler $\mathrm{C}$ and $\mathrm{N}$ molecules, facilitating a full oxidation to $\mathrm{CO}_{2}$ and $\mathrm{NO}_{\mathrm{x}}$. Particulate matter emissions associated with flaming combustion are relatively minor and smaller in size (e.g., $0.34-0.45 \mu \mathrm{m}$ ).

OC emitted from biomass burning, particularly with wet fuels, have TH/TC ratios similar to that of cellulous, the principle component of plant cells. However, the OC shows characteristics of $\mathrm{BrC}$, i.e., absorbing UV much more strongly than cellulous. Though it is possible that polyaccharides and other derivatives of cellulous dominate the OC mass, how $\mathrm{BrC}$ is formed and its chemical nature warrant further investigations.

This study confirms that fuel moisture content is a critical factor controlling the $\mathrm{C}$ and $\mathrm{N}$ partitioning in biomass burning emissions. Since high-moisture fuels lead to substantial $\mathrm{NH}_{3}$ and $\mathrm{OPN}$ emissions that have higher deposition rates, prescribed burning during wet seasons (e.g., spring in Lake Tahoe) would mitigate nutrient loss from long-range transport but increase the potential of nutrient deposition into the lake water. Distinct particle properties between lowand high-moisture fuel combustion imply different radiative effects of forest fires in dry and wet seasons. Moisturedependent EFs and emission mechanisms represent an important step towards establishing accurate biomass burning emission inventories and source functions for global and/or regional climate models.
Acknowledgements. This research was supported in part by the United States Bureau of Land Management through the Southern Nevada Public Land Management Act (SNPLMA Round 7) and by California Air Resources Board under contract number 04-307. The authors thank the Lake Tahoe Basin Management Unit of United States Forest Service and North Lake Tahoe Fire Protection District for their assistance in field survey and sample collection, and Russ Bergin, Nick Lumbreras, David Gibney, Steve Kohl, and Brenda Cristani for their assistance in the laboratories at the Desert Research Institute. The authors also thank Joint Fire Science Program and American Association for Aerosol Research for partially supporting the publication cost.

Edited by: H. Moosmüller

\section{References}

Andreae, M. O. and Gelencsér, A.: Black carbon or brown carbon? The nature of light-absorbing carbonaceous aerosols, Atmos. Chem. Phys., 6, 3131-3148, doi:10.5194/acp-6-3131-2006, 2006.

Andreae, M. O. and Merlet, P.: Emission of trace gases and aerosols from biomass burning, Global Biogeochem. Cy., 15, 955-966, 2001.

Carrico, C. M., Petters, M. D., Kreidenweis, S. M., Sullivan, A. P., McMeeking, G. R., Levin, E. J. T., Engling, G., Malm, W. C., and Collett Jr., J. L.: Water uptake and chemical composition of fresh aerosols generated in open burning of biomass, Atmos. Chem. Phys., 10, 5165-5178, doi:10.5194/acp-10-5165-2010, 2010.

Chakrabarty, R.K., Moosmüller, H., Garro, M.A., Arnott, W.P., Walker, J., Susott, R.A., Babbitt, R.E., Wold, C.E., Lincoln, E.N., and Hao, W.M.: Emissions from the laboratory combustion of wildland fuels: Particle morphology and size, J. Geophys. Res.Atmos., 111(D7), D07204, doi:10.1029/2005JD006659, 2006.

Chen, L.-W. A., Moosmüller, H., Arnott, W. P., Chow, J. C., Watson, J. G., Susott, R. A., Babbitt, R. E., Wold, C., Lincoln, E., and Hao, W. M.: Particle emissions from laboratory combustion of wildland fuels: In situ optical and mass measurements, Geophys. Res. Lett., 33, L04803, doi:10.1029/2005GL024838, 2006.

Chen, L.-W. A., Moosmüller, H., Arnott, W. P., Chow, J. C., Watson, J. G., Susott, R. A., Babbitt, R. E., Wold, C. E., Lincoln, E. N., and Hao, W. M.: Emissions from laboratory combustion of wildland fuels: Emission factors and source profiles, Environ. Sci. Technol., 41(12), 4317-4325, 2007.

Chow, J. C.: Critical review: Measurement methods to determine compliance with ambient air quality standards for suspended particles, J. Air Waste Manage. Assoc., 45(5), 320-382, 1995.

Chow, J. C., Watson, J. G., Chen, L.-W. A., Chang, M. C. O., Robinson, N. F., Trimble, D., and Kohl, S. D.: The IMPROVE_A temperature protocol for thermal/optical carbon analysis: Maintaining consistency with a long-term database, J. Air Waste Manage. Assoc., 57(9), 1014-1023, 2007a.

Chow, J. C., Watson, J. G., Kuhns, H. D., Etyemezian, V., Lowenthal, D. H., Crow, D. J., Kohl, S. D., Engelbrecht, J. P., and Green, M. C.: Source profiles for industrial, mobile, and area sources in the Big Bend Regional Aerosol Visibility and Observational (BRAVO) Study, Chemosphere, 54(2), 185-208, 2004.

Chow, J. C., Watson, J. G., Lowenthal, D. H., Chen, L. W. A., Zielinska, B., Mazzoleni, L. R., and Magliano, K. L.: Evalua- 
tion of organic markers for chemical mass balance source apportionment at the Fresno Supersite, Atmos. Chem. Phys., 7, 17411754, doi:10.5194/acp-7-1741-2007, 2007b.

Crounse, J. D., DeCarlo, P. F., Blake, D. R., Emmons, L. K., Campos, T. L., Apel, E. C., Clarke, A. D., Weinheimer, A. J., McCabe, D. C., Yokelson, R. J., Jimenez, J. L., and Wennberg, P. O.: Biomass burning and urban air pollution over the Central Mexican Plateau, Atmos. Chem. Phys., 9, 4929-4944, doi:10.5194/acp-9-4929-2009, 2009.

Crutzen, P. A. and Andreae, M. O.: Biomass burning in the tropics: Impact on atmospheric chemistry and biogeochemical cycles, Science, 250, 1669-1678, 1990.

Gani, A. and Naruse, I.: Effect of cellulose and lignin content on pyrolysis and combustion characteristics for several types, Renewable Energy, 32(4), 649-661, 2007.

Guyon, P., Graham, B., Beck, J., Boucher, O., Gerasopoulos, E., Mayol-Bracero, O. L., Roberts, G. C., Artaxo, P., and Andreae, M. O.: Physical properties and concentration of aerosol particles over the Amazon tropical forest during background and biomass burning conditions, Atmos. Chem. Phys., 3, 951-967, doi:10.5194/acp-3-951-2003, 2003.

IPCC: Climate Change 2007: The physical science basis. Summary for policymakers. Contribution of Working Group I to the Fourth Assessment Report of the Intergovernmental Panel on Climate Change, prepared by Intergovernmental Panel on Climate Change (IPCC), Geneva, Switzerland, 2007.

Janhäll, S., Andreae, M. O., and Pöschl, U.: Biomass burning aerosol emissions from vegetation fires: particle number and mass emission factors and size distributions, Atmos. Chem. Phys., 10, 1427-1439, doi:10.5194/acp-10-1427-2010, 2010.

Keil, A. and Haywood, J. M.: Solar radiative forcing by biomass aerosol particles over marine clouds during SAFARI-2000, J.Geophys.Res., 108(D13), 8467, doi:10.1029/2002JD002315, 2003.

Kirchstetter, T. W., Novakov, T., and Hobbs, P. V.: Evidence that the spectral dependence of light absorption by aerosols is affected by organic carbon, J. Geophys. Res.-Atmos., 109(D21), D21208, doi:10.1029/2004JD004999, 2004.

Kondo, Y., Morino, Y., Takegawa, N., Koike, M., Kita, K., Miyazaki, Y., Sachse, G. W., Vay, S. A., Avery, M. A., Flocke, F., Weinheimer, A. J., Eisele, F. L., Zondlo, M. A., Weber, R. J., Singh, H. B., Chen, G., Crawford, J., Blake, D. R., Fuelberg, H. E., Clarke, A. D., Talbot, R. W., Sandholm, S. T., Browell, E. V., Streets, D. G., and Liley, B.: Impacts of biomass burning in Southeast Asia on ozone and reactive nitrogen over the western Pacific in spring, J. Geophys. Res.-Atmos., 109, D15S12, doi:10.1029/2003JD004203, 2004.

Koppmann, R., von Czapiewski, K., and Reid, J. S.: A review of biomass burning emissions, part I: gaseous emissions of carbon monoxide, methane, volatile organic compounds, and nitrogen containing compounds, Atmos. Chem. Phys. Discuss., 5, 1045510516, doi:10.5194/acpd-5-10455-2005, 2005.

Kuhlbusch, T. A., Lobert, J. M., Crutzen, P. J., and Warneck, P.: Molecular nitrogen emissions from denitrification during biomass burning, Nature, 351, 6322, 135-137, 1991.

Lobert, J. M., Scharffe, D. H., Hao, W. M., and Crutzen, P. J.: Importance of biomass burning in the atmospheric budgets of nitrogen-containing gases, Nature, 346, 6284, 552-554, 1990.
Marjamäki, M., Lemmetty, M., and Keskinen, J.: ELPI response and data reduction - I: Response functions, Aerosol Sci. Technol., 39(7), 575-582, 2005.

McMeeking, G.R ., Kreidenweis, S. M., Baker, S., Carrico, C. M., Chow, J. C., Collett Jr., J. L., Hao, W. M., Holden, A. S., Kirchstetter, T. W., Malm, W. C., Moosmüller, H., Sullivan, A. P., and Wold, C. E.: Emissions of trace gases and aerosols during the open combustion of biomass in the laboratory, J. Geophys. Res.Atmos., 114, D19210, doi:10.1029/2009JD011836-2009.

Moosmüller, H., Chakrabarty, R. K., and Arnott, W. P.: Aerosol light absorption and its measurement: A review, J. Quant. Spectrosc. Radia. Trans., 110, 844-878, 2009.

Mukhtar, S., Rose, A. J., Capareda, S. C., Boriack, C. N., Lacey, R. E., Shaw, B. W., and Parnell Jr., C. B.: Assessment of ammonia adsorption onto Teflon and LDPE tubing used in pollutant stream conveyance, Agricultural Engineering International: the CIGR Journal of Scientific Research and Development, Manuscript BC 03 012, Vol. V, Paper 29, 1-13, 2003.

Murphy, J. D., Johnson, D. W., Miller, W. W., Walker, R. F., Carroll, E. F., and Blank, R. R.: Wildfire effects on soil nutrients and leaching in a Tahoe basin watershed, J. Environ. Qual., 35, 479489, 2006.

Neirynck, J., Kowalski, A. S., Carrara, H., Genouw, G., Berghmans, P., and Ceulemans, R.: Fluxes of oxidised and reduced nitrogen above a mixed coniferous forest exposed to various nitrogen emission sources, Environ. Pollut., 149(1), 31-43, 2007.

Reid, J. S., Eck, T. F., Christopher, S. A., Koppmann, R., Dubovik, O., Eleuterio, D. P., Holben, B. N., Reid, E. A., and Zhang, J.: A review of biomass burning emissions part III: intensive optical properties of biomass burning particles, Atmos. Chem. Phys., 5, 827-849, doi:10.5194/acp-5-827-2005, 2005a.

Reid, J. S., Koppmann, R., Eck, T. F., and Eleuterio, D. P.: A review of biomass burning emissions part II: intensive physical properties of biomass burning particles, Atmos. Chem. Phys., 5, 799825, doi:10.5194/acp-5-799-2005, 2005b.

Rinehart, L. R., Fujita, E. M., Chow, J. C., Magliano, K. L., and Zielinska, B.: Spatial distribution of $\mathrm{PM}_{2.5}$ associated organic compounds in central California, Atmos. Environ., 40(2), 290303, 2006.

Simoneit, B. R. T., Schauer, J. J., Nolte, C. G., Oros, D. R., Elias, V. O., Fraser, M. P., Rogge, W. F., and Cass, G. R.: Levoglucosan, a tracer for cellulose in biomass burning and atmospheric particles, Atmos. Environ., 33(2), 173-182, 1999.

Sinha, P., Hobbs, P. V., Yokelson, R. J., Blake, D. R., Gao, S., and Kirchstetter, T. W.: Emissions from miombo woodland and dambo grassland savanna fires, J. Geophys. Res.-Atmos., 109(D11), D11305, doi:10.1029/2004JD004521, 2004.

Vitousek, P. M., Aber, J. D., Howarth, R. W., Likens, G. E., Matson, P. A., Schindler, D. W., Schlesinger, W. H., and Tilman, D. G.: Human alteration of the global nitrogen cycle: sources and consequences, Ecol. Appl., 7(3), 737-750, 1997.

Yokelson, R. J., Griffith, D. W. T., and Ward, D. E.: Openpath Fourier transform infrared studies of large-scale laboratory biomass fires, J. Geophys. Res., 101(D15), 21067-21080, 1996. 